IOSR Journal of Pharmacy

ISSN: 2250-3013, www.iosrphr.org

||| Volume 2 Issue 5 |||| Sep-Oct. 2012 ||| PP.38-43

\title{
Hepatoprotective effect of amomum subulatum roxb seeds on carbon tetrachloride-induced liver damage in rats
}

\author{
Mihir Y. Parmar*1,2, Purvi A. Shah², Vaishali T. Thakkar², \\ Salim S. Al-Rejaie ${ }^{1}$, Tejal R. Gandhi ${ }^{2}$ \\ ${ }^{I}$ Department of Centre for Experiment on Animal, College of Pharmacy, King Saud University, \\ P.O. Box 2457, Riyadh 11451, Saudi Arabia. \\ ${ }^{2}$ Anand Pharmacy College, Shree Ram Krishna Seva Mandal, Opp. Town Hall, Sardar Patel \\ University, Anand-388001, Gujarat, India.
}

\begin{abstract}
Aims of study: - The aim of the present study is to evaluate the protective effect of Amomum subulatum seeds against experimentally induced liver injury.

Materials and methods: - The methanolic extract of seeds of Amomum subulatum (MEAS) was evaluated for the hepatoprotective effect against carbon tetrachloride $\left(\mathrm{CCl}_{4}\right)$ induced hepatotoxicity in rats. Various biochemical parameters like alanine amino transferase (ALT), aspartate amino transferase (AST), alkaline phosphatase (ALP), total bilirubin (TB) and total protein (TP) levels were estimated in serum as well as the glutathione (GSH) and malondialdehyde (MDA) levels in the liver were determined. Histopathological changes in the liver of different groups were also studied.

Results:- The pre-treatment of MEAS at dose levels of 100 and $300 \mathrm{mg} / \mathrm{kg} / \mathrm{d}$, p.o. for $7 \mathrm{~d}$ had controlled the raise of AST, ALT, ALP, TB and MDA levels and the effects were comparable with standard drug (silymarin $200 \mathrm{mg} / \mathrm{kg} / \mathrm{d}$, p.o. for $7 \mathrm{~d}$ ). The GSH and TP levels were significantly increased in the animals received pretreatment of the extract. The animals received pre-treatment of the extract shown decreased necrotic zones and hepatocellular degeneration when compared to the liver exposed to $\mathrm{CCl}_{4}$ intoxication alone. Thus the histopathological studies also supported the protective effect of the extract.

Conclusion: - This study demonstrates the hepatoprotective effect of Amomum subulatum seeds and thus scientifically supports the usage of this plant in various Ayurvedic preparations and traditional medicine for treatment of liver disorders.
\end{abstract}

Keywords: Amomum subulatum, hepatoprotective effect, $\mathrm{CCL}_{4}$

\section{INTRODUCTION}

Liver is the organ for metabolism and detoxification of various components enter into the body. It is involved in wide range of functions and hence it is exposed to toxic substances and drugs absorbed from the intestine. Apart from the toxins and drugs (Marina, 2006), viral infections (hepatitis A, B, C, D, etc.) and microbial infections of Entamoeba histolytica (Sharma and Ahuja, 1997) also cause damage to the hepatocytes. Globally, plant based drugs like Silybum marianum (Scott Luper, 1998), Picrorhiza kurroa (Chander et al., 1992), Phyllanthus emblica (Gulati et al., 1995), etc. are widely and successfully used in the treatment of liver disorders.

Amomum subulatum (Zingiberaceae) is commonly known as greater cardamom, is a perennial herb which grows widely in moist tropical countries. It is one of the plants mentioned in literature having claims of activity against liver disorders (Sharma et al., 2002). It contains a wide variety of phytoconstituents includes flavonoids, terpenoids, glycosides and volatile oils (Parmar et al., 2009).

Plant derived natural products such as flavonoids (Defeudis et al., 2003) terpenoids (Takeoka et al., 2003), glycosides (Quyang et al., 2003), volatile oils (Hikino et al., 1986), steroids (Banskota et al., 2000), saponins (Yohikawa et al., 2003), alkaloids (Janbaz et al., 2000) and tannins (Gilani et al., 1995) have received considerable attention in recent years due to their diverse pharmacological properties including antioxidant and hepatoprotective activity. There has been a growing interest in the analysis of above compounds stimulated by intense research into their potential benefits to human health. Antioxidants play an important role in inhibiting and scavenging radicals, thus providing protection to humans against infection and degenerative diseases. Realizing the fact, this research was carried out to evaluate the hepatoprotective effect of $A$. subulatum seeds against $\mathrm{CCL}_{4}$ - induced liver damage in rats. 
Hepatoprotective effect of amomum subulatum roxb seeds on carbon tetrachloride...

Plant material and extraction:

\section{MATERIALS AND METHODS}

A. subulatum fruits were purchased from a local market of Anand, India, during July 2007. The fruits were identified and authenticated by Dr. A. S. Reddy, Department of Biosciences, Sardar Patel University, Vallabh Vidyanagar, Gujarat, India where a voucher specimen (No. MP-2: 28/7/2007) was kept for future reference. The seeds were dried at room temperature and mechanically powdered to obtain a coarse powder; defatted with petroleum ether $\left(60-80^{\circ} \mathrm{C}\right)$ and cold extracted with methanol. The methanol crude extract $(9.5 \%$ yields) was obtained by evaporation using Rotavapour ${ }^{\circledR}(\mathrm{BÜUCHI}$, Switzerland) under reduced pressure.

Animals:

Studies were carried out using either sex Wistar albino rats (200-220 g). They were obtained from the animal house, Anand pharmacy college (APC), Anand, India. The animals were grouped and housed in polyacrylic cages $(38 \times 23 \times 10 \mathrm{~cm})$ with not more than six animals per cage and maintained under standard laboratory conditions; temperature $\left(22 \pm 2{ }^{\circ} \mathrm{C}\right)$, relative humidity $(55 \pm 5 \%)$ with dark and light cycle $(12 / 12 \mathrm{~h})$. They were allowed free access to standard pellet diet (Amrut feed, Sangli, India) and water ad libitum. The rats were acclimatized to laboratory condition for 10 days before commencement of experiment. Animal studies were approved by the Committee for the Purpose of Control and Supervision of Experiments on Animals (CPCSEA) and conducted according to the regulations of Institutional Animal Ethics Committee (Protocol no. 7004 dated 07/08/07).

Drugs and Chemicals:

$\mathrm{CCL}_{4}$ was purchased from S. D. Fine Chem. Ltd. (Mumbai). Silymarin was obtained as a gift sample from Micro labs, Bangalore, India. SGOT, SGPT, ALP, Bilirubin kits were procured from Span Diagnostics, Surat, India. LDH, GGT kits were procured from Coral Clinical Systems, Goa, India. Trichloroacetic acid was purchased from Merck India Ltd. (Mumbai). Thiobarbituric acid and Di thiobis Nitro Benzoic Acid were purchased from Himedia, Mumbai, India. All other chemicals and reagents used were of analytical grade.

Acute Toxicity Studies:

Healthy adult Wistar albino rats of either sex weighing between 200 to $220 \mathrm{~g}$ were subjected to acute toxicity studies as per guidelines (AOT no. 425) suggested by the Organization for Economic Cooperation and Development (OECD, 2001) using stair case method. The mice were observed continuously for $2 \mathrm{~h}$ for behavioral, neurological and autonomic profiles for any lethality or death for the next $48 \mathrm{~h}$.

Carbon tetrachloride-induced liver damage in rats: (Shenoy AK et al., 2001)

Animals were randomly divided into five groups six of each. All animals except normal control group were intoxicated with $\mathrm{CCL}_{4}(0.5 \mathrm{ml} / \mathrm{kg} / \mathrm{d}$, i.p. for $7 \mathrm{~d})$. Group I (Normal control) received only distilled water and Group II ( $\mathrm{CCL}_{4}$ control) received $\mathrm{CCL}_{4}(0.5 \mathrm{ml} / \mathrm{kg} / \mathrm{d}$, i.p. for $7 \mathrm{~d})$. Group III (Test-1) and Group IV (Test-2) received methanol extract of $A$. subulatum at $100 \mathrm{mg} / \mathrm{kg}$ and $300 \mathrm{mg} / \mathrm{kg} / \mathrm{d}$, p.o for $7 \mathrm{~d}$. respectively while Group V (Standard control) received silymarin $(200 \mathrm{mg} / \mathrm{kg} / \mathrm{d}$, p.o for $7 \mathrm{~d})$. The blood was withdrawn $24 \mathrm{~h}$ after the administration of last dose under anaesthesia using thiopentone sodium ( $35 \mathrm{mg} / \mathrm{kg}$, i.p.). The blood is allowed to stand for $30 \mathrm{~min}$ at room temperature and then centrifuged to separate the serum. The liver was quickly removed and perfused immediately with ice-cold saline $(0.9 \% \mathrm{NaCl})$. A portion of the liver was homogenized in chilled sodium phosphate buffer $(0.1 \mathrm{M}, \mathrm{pH} 7.4)$ using a Potter Elvehjehm Teflon homogenizer. The homogenate obtained was centrifuged in a cooling centrifuge at $12,000 \times g$ for $30 \mathrm{~min}$ at $4{ }^{\circ} \mathrm{C}$ to obtain a post-mitochondrial supernatant (PMS) which was used for enzyme analysis. A portion of PMS was centrifuged at $105,000 \times g$ for $1 \mathrm{~h}$ at $4^{\circ} \mathrm{C}$. The pellet was first washed and then suspended in sodium phosphate buffer $(0.1 \mathrm{M}, \mathrm{pH} 7.4)$.

Estimation of biochemical parameters

The separated serum was estimated for various biochemical parameters like ALT, AST (Reitman and Frankel, 1957) ALP (Kind and King, 1954), TB (Malloy and Evelyn, 1937) and TP (Lowry OH et al.,1951) levels. The contents of glutathione (GSH) and malondialdehyde (MDA) in the liver were determined by the methods of Ellman (1959) and Ohkawa et al. (1979), respectively.

Histopathological studies

A portion of the liver was cut into two to three pieces of approximately $6 \mathrm{~mm} 3$ size and fixed in phosphate buffered $10 \%$ formaldehyde solution. After embedding in paraffin wax, thin sections of $5 \mu \mathrm{m}$ thickness of liver tissue were cut and stained with haematoxylin-eosin. The thin sections of liver were made into permanent slides and examined (Valeer, 2003) under high-resolution microscope with photographic facility and photomicrographs were taken.

\section{STATISTICAL ANALYSIS}

All values are expressed as mean \pm SEM. Statistical analysis were performed by one-way Analysis of Variance (ANOVA) and individual comparisons of the group mean values were done using Dunnet's t-test, with the help of Graph Pad prism 5.0 software. The value of $\mathrm{P}$ lower than 0.05 were considered as significant $(\mathrm{P}$ is probability) (Dunnet, 1964; Osel et al., 1975). 
Hepatoprotective effect of amomum subulatum roxb seeds on carbon tetrachloride...

\section{RESULTS}

Acute toxicity studies

The acute toxicity study exhibited no mortality up to a dose level of $2000 \mathrm{mg} / \mathrm{kg} / \mathrm{d}$, p.o. As per the ranking system European Economic Community (EEC) for acute oral toxicity, the LD50 dose of $2000 \mathrm{mg} / \mathrm{kg}$ and above is categorized as unclassified (EC Directive 83/467/EEC, 1983).

Evaluation of hepatoprotective activity

The results observed in pre-treatment of MEAS with respect to induction of hepatotoxicity using $\mathrm{CCl}_{4}$ were given in Table 1 . Rats treated with $\mathrm{CCl}_{4}$ developed significant $(P<0.001)$ liver damage and it was well indicated by elevated levels of hepatospecific enzymes like ALT, AST and ALP in serum. A marked elevation in TB level was observed in the group treated with $\mathrm{CCl}_{4}$ and they were significantly high when compared with the normal values. The TP levels decreased considerably $(P<0.001)$ in the toxic group. The MDA and GSH levels in the liver homogenate were also significantly altered in the group received $\mathrm{CCl}_{4}$ alone.

Table 1. Hepatoprotective effect of $A$. Subulatum seeds on $\mathbf{C C l}_{4}$ induced-hepatotoxicity in rats.

\begin{tabular}{|c|c|c|c|c|c|c|c|}
\hline Group & $\begin{array}{l}\text { AST } \\
(\text { IU/L) }\end{array}$ & $\begin{array}{l}\text { ALT } \\
(\text { IU/L) }\end{array}$ & $\begin{array}{l}\text { ALP } \\
(\text { KAU/dl) }\end{array}$ & $\begin{array}{l}\text { TBL } \\
\text { (mg/dl) }\end{array}$ & $\begin{array}{l}\text { TP } \\
(\mathrm{mg} / \mathrm{ml})\end{array}$ & $\begin{array}{l}\text { MDA } \\
\text { ( } \mu \mathrm{g} / \mathrm{mg} \\
\text { protein) }\end{array}$ & $\begin{array}{l}\text { GSH } \\
\text { ( } \mu \mathrm{g} / \mathrm{mg} \text { protein) }\end{array}$ \\
\hline $\begin{array}{l}\text { Normal } \\
\text { control }\end{array}$ & $33.5 \pm 4.7$ & $28.17 \pm 2.1$ & $7.18 \pm 0.7$ & $0.36 \pm 0.04$ & $7.69 \pm 0.8$ & $0.26 \pm 0.02$ & $12.19 \pm 1.6$ \\
\hline $\begin{array}{l}\mathrm{CCl}_{4} \\
\text { control } \\
(0.5 \mathrm{ml} / \mathrm{kg})\end{array}$ & $168.3 \pm 14.9^{\# \#}$ & $185.00 \pm 14.9^{\#}$ & $95.90 \pm 5.8^{\# \#}$ & $1.68 \pm 0.14^{\# \#}$ & $3.02 \pm 0.4^{\# \#}$ & $1.81 \pm 0.20^{\# \#}$ & $6.53 \pm 1.02^{\#}$ \\
\hline $\begin{array}{l}\text { Test-1 } \\
(100 \\
\text { mg/kg) }\end{array}$ & $68.83 \pm 3.9 * *$ & $65.67 \pm 5.9 * *$ & $26.11 \pm 1.7 * *$ & $0.58 \pm 0.04 * *$ & $7.07 \pm 0.6 * *$ & $0.59 \pm 0.05 * *$ & $11.61 \pm 1.59 * *$ \\
\hline $\begin{array}{l}\text { Test-2 } \\
(300 \\
\mathrm{mg} / \mathrm{kg})\end{array}$ & $62.33 \pm 2.5 * *$ & $58.67 \pm 3.8 * *$ & $18.40 \pm 2.1 * *$ & $0.49 \pm 0.05 * *$ & $7.20 \pm 0.5^{* *}$ & $0.45 \pm 0.07 * *$ & $11.99 \pm 1.08 * *$ \\
\hline $\begin{array}{l}\text { Standard } \\
\text { Control } \\
(200 \\
\mathrm{mg} / \mathrm{kg})\end{array}$ & $51.67 \pm 4.4 * *$ & $58.33 \pm 3.1 * *$ & $15.13 \pm 1.6 * *$ & $0.46 \pm 0.1 * *$ & $7.50 \pm 0.6 * *$ & $0.44 \pm 0.06 * *$ & $12.07 \pm 1.09 * *$ \\
\hline
\end{tabular}

Values are expressed as mean $\pm \mathrm{SEM} ; \mathrm{n}=6$ rats in each group; ${ }^{\#} \mathrm{P}<0.05$ and ${ }^{\# \#} \mathrm{P}<0.001$ compared with Normal control; * $\mathrm{P}<0.05$, ** $\mathrm{P}<0.001$ compared with $\mathrm{CCl}_{4}$ control.

The groups received the pre-treatment of MEAS at dose levels of 100 and $300 \mathrm{mg} / \mathrm{kg}$ significantly controlled the change in the biochemical parameters. The extract at a dose level of $300 \mathrm{mg} / \mathrm{kg}$ exhibited a sharp decrease in the serum enzyme levels and the effect was comparable with the standard group treated with silymarin $(200 \mathrm{mg} / \mathrm{kg})$. The TP and GSH levels were significantly $(P<0.001)$ increased in groups received MEAS at dose levels of 100 and $300 \mathrm{mg} / \mathrm{kg}$. The increase in dose levels of MEAS exhibited an increase in efficacy which was reflected in the values of biochemical parameters. The histopathological studies also supported the protective properties of MEAS. The areas of necrosis and ballooning degeneration of hepatocytes were observed in the toxic group. The group of animals pre-treated with MEAS showed a marked protective effect with decreased necrotic zones and hepatocellular degeneration. The photomicrographs of the liver sections were given in Fig. 1. 

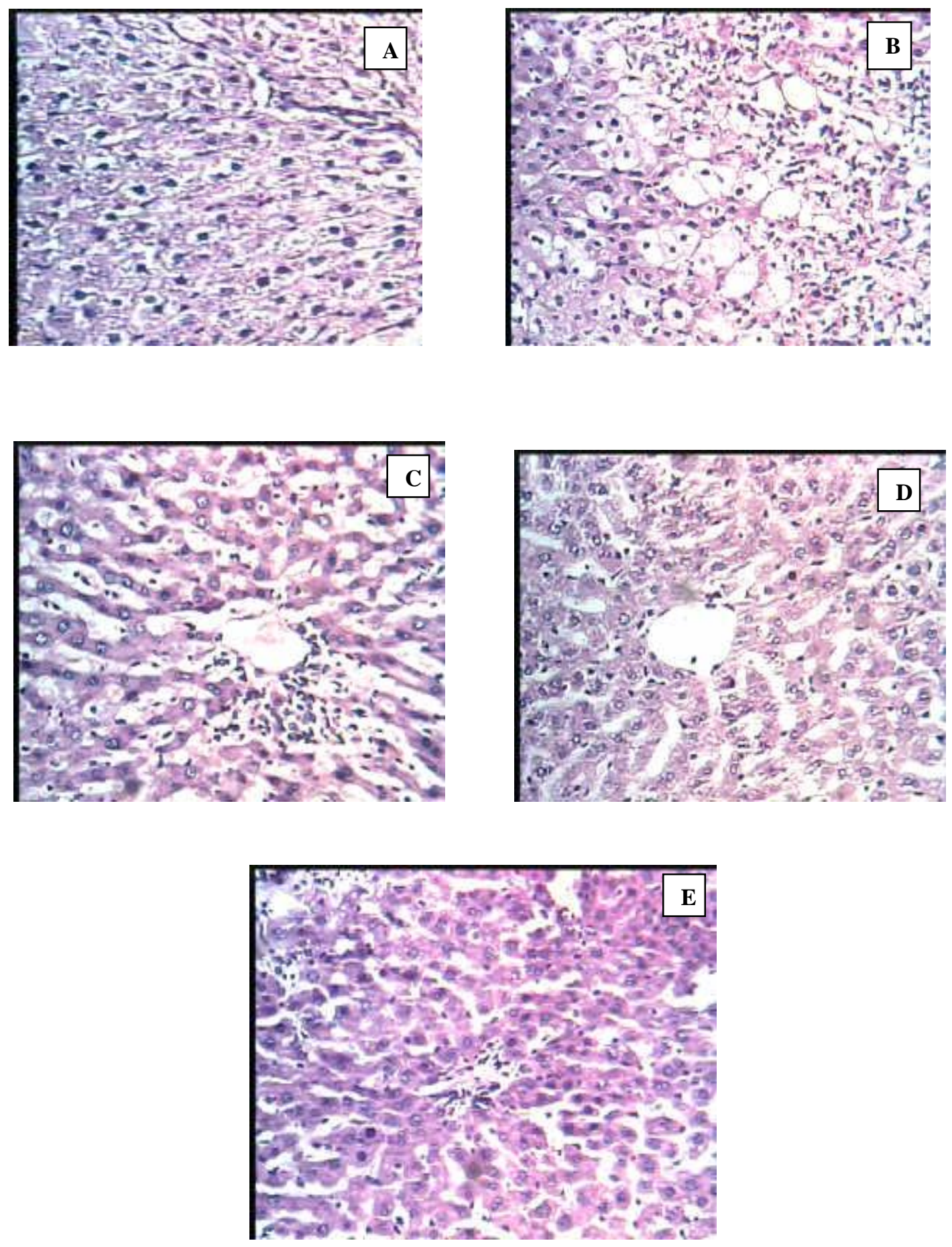

Fig. 1. Photomicrographs (original magnification $45 \times$ ) of histopathological studies of livers of various groups stained with haematoxylin and eosin (A). Normal architecture of rat liver (B). Necrosis and hepatocellular degeneration of $\mathrm{CCl}_{4}$ intoxicated $(\mathrm{C}, \mathrm{D} \& \mathrm{E})$. Lesser damage of hepatocytes and low index of necrosis in MEAS $(100,300 \mathrm{mg} / \mathrm{kg})$ and Silymarin pre-treated group. 
Hepatoprotective effect of amomum subulatum roxb seeds on carbon tetrachloride...

\section{DISCUSSION}

The hepatotoxic agent $\mathrm{CCl}_{4}$ induces selective toxicity to the liver cells due to metabolic activation and this maintains them with semi normal metabolic function. It also causes functional and morphological changes in the cell membrane which may lead to cell death (Recknagel et al., 1989). The hepatic cells consist of higher concentrations of AST and ALT in cytoplasm and AST in particular exists in mitochondria (Wells, 1988). Due to the damage caused to hepatic cells, the leakage of plasma (Zimmerman and Seef, 1970) causing an increased levels of hepatospecific enzymes in serum.

The elevated serum enzyme levels like AST and ALT are indicative of cellular leakage and functional integrity of cell membrane in liver (Drotman and Lawhorn, 1978). The hepatoprotective index of a drug can be evaluated by its capability to reduce the injurious effects or to preserve the normal hepatic physiological mechanisms, which have been induced by a hepatotoxin.

The measurement of serum AST, ALT and ALP levels serve as a means for the indirect assessment of condition of liver. The pre-treatment of the animals with MEAS with respect to intoxication with $\mathrm{CCl}_{4}$ controlled the AST, ALT and ALP levels when compared with the toxic group. A high concentration of bilirubin in serum is an indication for increased erythrocyte degeneration rate (Singh et al., 1998). Due to the liver injury caused by the hepatotoxin, there is a defective excretion of bile by the liver which is reflected in their increased levels in serum (Rao, 1973). The oral administration of MEAS at 100 and $300 \mathrm{mg} / \mathrm{kg}$ effectively reduced the serum TB levels.

The TP levels will be depressed in hepatotoxic conditions due to defective protein biosynthesis in liver (Clawson, 1989). The $\mathrm{CCl}_{4}$ intoxication causes disruption and disassociation of polyribosomes on endoplasmic reticulum and thereby reducing the biosynthesis of protein.

The pre-treatment of MEAS well restored the proteins synthesis by protecting the polyribosomes. The increase in MDA or decrease in GSH levels indicates the lipid peroxidation. MDA is one among the end products produced by the decomposition of $\omega 3$ and $\omega 6$ poly-unsaturated fatty acids (Parola et al., 1999). GSH play a vital role in the defence mechanism of tissue against the reactive oxygen species (Kosover and Kosover, 1976). The groups received the $\mathrm{CCl}_{4}$ treatment alone were prone to high lipid peroxidation, whereas the groups received the pre-treatment of MEAS exhibited significant protection.

This also suggests the defence mechanism against the reactive oxygen species and thereby the antioxidant potential of MEAS. The histopathological studies are direct means for assessing the protective effect of the drug. The groups received $\mathrm{CCl}_{4}$ alone, the damage of cells around the central vein were well evident. Whereas, the intensity of damage was found lesser in the studies involved pre-treatment of MEAS. The results of the histopathological studies supported and well correlated with data obtained from evaluation of the biochemical parameters.

\section{CONCLUSION}

The methanolic extract of could effectively control the AST, ALT, ALP and TB levels and increased the protein levels in the protective studies. The protective effect of MEAS may be attributed due to the reduced lipid peroxidation and improved defence of the hepatocytes against the reactive oxygen species. The histopathological studies also substantiate the activity of the drug. Therefore the study scientifically supports the usage of this plant in various Ayurvedic preparations and traditional medicine for treatment of liver disorders and as a tonic.

\section{ACKNOWLEDGEMENT}

The authors express sincere thanks to Dr. A. S. Reddy, Professor, BRD School of biosciences, S. P. University, V. V. Nagar for the authentication of the plant. The authors also thank Dr. Prera Desai, Ayurvedic practitioner for her interest and encouragement.

The authors extend their appreciation to the Deanship of Scientific Research at King Saud University for funding the work through the research group project No RGP-VPP-179.

\section{REFERENCES}

[1]. Banskota AH, Tezuka Y, Adnyana IK, Xiong Q, Hase K, Tran KQ. (2000) Hepatoprotective effect of Commbretum quadrangulare and its constituents. Biol Pharm Bull, 23: 456-60.

[2]. Chander R, Kapoor NK, Dhawan BN. (1992) Effect of picroliv on glutathione metabolism in liver and brain of Mastomys natalensis infected with Plasmodium berghei. Indian J Exp Biol. 30, 711-714.

[3]. Clawson GA. (1989) Mechanism of carbon tetrachloride hepatotoxicity. Pathol and Immunopathol Res 8, 104-112.

[4]. Defeudis FV, Papadopoulos V, Drieu K. (2003) Ginkgo biloba extracts and cancer: a research area in its infancy. Fundam Clin Pharmacol, 17: 405-17. 
Hepatoprotective effect of amomum subulatum roxb seeds on carbon tetrachloride...

[5]. Drotman RB. Lawhorn GT. (1978) Serum enzymes as indicators of chemical induced liver damage. Drug and Chemical Toxicol 1, 163-171.

[6]. Dunnet CW. (1964) New tables for multiple comparisons with a control. Biometrics 20, 482-491.

[7]. Ellman GL. (1959) Tissue sulphydril groups. Arch of Biochem and Biophysics 82, 70-77.

[8]. Gilani AH, Janbazz KH (1995). Preventive and curative effects of Artemisia absinthium on paracetamol and $\mathrm{CCl}_{4}$-induced hepatotoxicity. Gen Pharmacol 26,309-15.

[9]. Gulati RK, Agarwal S, Agrawal SS. (1995) Hepatoprotective studies on Phyllanthus emblica Linn. and quercetin. Indian J of Experimental Biol 33, 261-268.

[10]. Hikino H, Tohkin M, Kiso Y, Namiki T, Nishimura S, Takeyama K. (1986) Antihepatoxic actions of Allium sativum bulbs. Planta Med, 53: 163.

[11]. Janbaz KH, Gilani AH. (2000) Studies on preventive and curative effects of berberine on chemical induced hepatotoxicity in rodents. Fitoter, 71:25.

[12]. Kind PRN, King EJJ. (1954) Estimation of plasma phosphatase by determination of hydrolyzed phenol with aminopyrines. J of Clin Pathol 7, 332.

[13]. Kosover EM, Kosover NS. (1976) Glutathione Metabolism and Function. pp. 139, Raven Press, New York.

[14]. Lowry OH, Rosebrough NJ, Farr AL, Randall RJ. (1951) Protein measurement with the folin phenol reagent. J Biol Chem. 193, 65-75.

[15]. Malloy HJ, Evelyn KA. (1937) The determination of bilirubin with the photoelectric colorimeter. J Biol Chem 119 , 481.

[16]. Marina N. (2006) Hepatotoxicity of antiretrovirals: incidence, mechanisms and management. J of Hepatol 44, S132-S139.

[17]. OECD. (2001) Acute oral Toxicity-Acute oral toxic class method. Guideline, 425 adopted 23.03.1996. In: Eleventh Addendum to the OECD guidelines for the Testing of Chemicals. Organisation for Economic CoOperation and Development, Stair case Procedure, Paris, (www.oecd.org/ehs).

[18]. Ohkawa H, Ohishi N, Yagi K. (1979) Assay for lipid peroxides in animal tissues by thiobarbituric acid reaction. Anal Biochem 95, 315-318.

[19]. Osel A, Gennaro AR, Martin AN. (1975) Remington's Pharmaceutical Science. Fifteenth edn. pp. 245, Mark Publishing Company, Pennsylvania.

[20]. Parmar MY, Shah PA, Thakkar VT, Gandhi. TR. (2009) Hepatoprotective activity of A. Subulatum Roxb seed against ethanol-induced liver damage in rats. Int J Green Pharm 3 (3): 250-54.

[21]. Parola M, Bellomo G, Robino G, Barrera G, Dianzani MU. (1999) 4- Hydroxynonenal as a biological signal: molecular basis and pathophysiological implications. Antioxidants and Redox Signaling 1, 255-284.

[22]. Quyang MA, He ZD, Wu CL. (2003) Antioxidative activity of glycosides from Ligustrum sinense. Nat Prod Res, 17: 381 .

[23]. Rao RR. (1973) Mechanism of drug induced hepatotoxicity. Indian J of Pharmacol 5, 313-318.

[24]. Recknagel RO, Glende EA, Dolak JA, Waller RL. (1989) Mechanisms of carbon tetrachloride toxicity. Pharmacol and Ther 43, 139-154.

[25]. Reitman S. Frankel S. (1957) A colorimetric method for the determination of serum glutamic oxaloacetic acid and glutamic pyruvic transaminases. Am J of Clin Pathol 28, 56-63.

[26]. Scott Luper ND. (1998) A review of plants used in the treatment of liver disease: part1. Alt Med Rev 3, 410-419.

[27]. Sharma MP, Ahuja V. (1997) Amoebic liver abscess: clinicians perspective. Bombay Hospital Journal 39, 615619.

[28]. Sharma PC, Yelne MB, Dennis TJ. (2002) Database on Medicinal Plants used in Ayurveda, pp. 454-61, Vol-2, New Delhi: CCRAS.

[29]. Shenoy AK, Somayaji N, Bairy KL. (2001) Hepatoprotective effects of Ginkgo biloba against $\mathrm{CCl}_{4}$ induced hepatic injury in rats. Indian J Pharmacol 33: 260-66.

[30]. Singh B, Saxena AK, Chandan BK, Anand KK, Suri OP, Suri KA, Satti NK. (1998) Hepatoprotective activity of verbenalin on experimental liver damage in rodents. Fitoter 69, 135-140.

[31]. Takeoka GR, Dao LT. (2003) Antioxidant constituent of almond [Prunus dulcis (Mill.) Webb DA] Hulls. J Agric Food Chem, 51: 496-501.

[32]. Valeer JD. (2003) Liver tissue examination. J of Hepatol 39, S43-S49.

[33]. Wells FE. (1988) Tests in liver and biliary tract disease. In: Gowenlock, H.A. (Ed.), Varley's Practical Clinical Biochemistry. CRC Press, Florida.

[34]. Yohikawa M, Morikawa T, Kashima Y, Ninomiya K, Matsuda H. (2003) Structure of New dammarane type triterpene saponins from the flower buds of Panax notoginseng and hepatoprotective effects of principal ginseng saponins. J Nat Prod, 66: 922.

[35]. Zimmerman HJ, Seef LB. (1970) Enzymes in hepatic disease. In: Goodly, E.I. (Ed.), Diagnostic Enzymology. Lea and Febiger, Philadelphia. 